\title{
Effect of discontinuous curing and ambient temperature on the compressive strength development of fly ash based Geopolymer concrete
}

\author{
Bayrak Almuhsin ${ }^{1, *}$, Tareq al-Attar ${ }^{1}$, and Qais Hasan $^{1}$ \\ ${ }^{1}$ Building and Construction Engineering Department, University of Technology, Baghdad, Iraq
}

\begin{abstract}
In the current study, 6 mixtures of Geopolymer concrete have been studied. The effect of discontinuous curing in oven and in atmosphere ambient temperature has been inspected by exposing the Geopolymer concrete specimens to temperature in the oven for few hours then stopping the oven to let it cool down to the ambient temperature. The compressive strength test of 100x200 mm cylindrical specimens for each mixture has been performed at different ages. It was found that the ambient temperature has vast effect on the compressive strength of the Geopolymer concrete in discontinuous curing. Discontinuous curing saves energy and can be a good replacement to the continuous curing when the ambient temperature is $40^{\circ} \mathrm{C}$ or more. Specimens that were cured continuously in ambient temperature of $43^{\circ} \mathrm{C}$ has resulted in compressive strength of $23 \mathrm{MPa}$ at age of 40 days; to enhance the compressive strength, it is advised to impose few hours of discontinuous oven curing. It was also found that the rest period (starts when pouring concrete in forms and ends when imposing oven curing to the Geopolymer) has a positive influence on the compressive strength of Geopolymer concrete, but when no rest period is allowed, the later ages compressive strength is remarkably higher.
\end{abstract}

\section{Introduction}

Geopolymer concrete or so-called mineral-polymer concrete is one of the promising innovations in the concrete industry [1]. It has mainly attracted the attention of the scientists and the concrete industry entities as an alternative to conventional concrete because of being much more environmental friendly than the latter. Large amount of carbon dioxide is being released into the air during the manufacturing of Portland cement [2, 3]. For producing one ton of Portland cement, one ton of Carbon dioxide is emitted to the atmosphere [4]. Knowing that concrete is the second most consumed material, just below water, with an annual consumption of (4180) metric tons/ year (as for 2014) [5]. The result is (4180) metric tons/ year of Carbon dioxide is being added to the atmosphere every year from the production of Portland cement that will be used for the manufacturing of the conventional concrete.

Portland cements paste gains strength from the process of hydration that results in C-S-H gel. The mechanism of developing strength in Geopolymer is explained by the poly-condensation of the precursors of silica and alumina.

Mineral-polymer results from the polymerization of materials that alumina and silica constitutes most of its contents. To enforce the polymerization of the aluminasilica enriched materials, an alkaline activator such as sodium hydroxide and sodium silicate solution is to be added. The addition of the alkaline solution results in the dissolving of the oxide minerals from the silica-alumina

\footnotetext{
* Corresponding author: bayrak.almuhsin@yahoo.com
}

oxides and finally poly-condensation to form the final stable silico-aluminate product [6]. The production of the Geopolymer can be as described below:

$$
\begin{aligned}
& \left.n\left(\mathrm{Si}_{2} \mathrm{O}_{5}, \mathrm{Al}_{2} \mathrm{O}_{2}\right)+2 \mathrm{nSiO}_{2}+4 \mathrm{nH}_{2} \mathrm{O} \stackrel{\mathrm{NaOH}, \mathrm{KOH}}{\longrightarrow} \mathrm{n}(\mathrm{OH})_{3} \text {-Si-O-Al-O-Si-(OH }\right)_{3}
\end{aligned}
$$

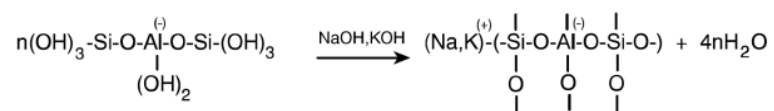

In spite of the fact that since Davidovits has published his innovations in Geopolymer binders and cements and many researchers have studied the physical and chemical properties of the Geopolymer and the production of it for various uses, none of the concrete standardization entities have adopted standard procedures for producing Geopolymer concrete. Thus, more information are required to provide more knowledge for the database in the field to be enriched with more aspects resulting in better understanding of the physical and chemical properties that contribute to the Geopolymer concrete properties.

The advantages of Geopolymer concrete to the environment and the durability of it are considered much higher than those of the Portland cement concrete and make it a good replacement to the conventional Portland cement.

One of the innovative developments in concrete industry is the high range water reducing agents (HRWRA) which is necessary for workable and durable concrete. HRWRA enhance the fresh properties of the concrete, and improve hardened concrete properties, 
particularly, the durability of the hardened concrete [7-11].

Due to the advantages of the HRWRA to the industry of concrete, the Geopolymer concrete, as a potential alternative to Portland cement concrete, needs to be investigated for the appropriate type of HRWRA for Geopolymer concrete. The current study used naphthalene-based superplasticizer to get the required workability and to enhance the compressive strength of the Geopolymer concrete.

\section{Experimental Work}

For the production of the Geopolymer for the research program, the following materials were used: fly ash class F, sodium hydroxide flakes, sodium silicate liquid, crushed gravel, sand, superplasticizer, and tap water.

\subsection{Materials}

\subsubsection{Fly ash}

Electrical power generation plants that use coal as a fuel in the boilers extract large amounts of fly ash as a byproduct for the combustion process [12]. Fly ash is a fine powdered material consisting of fine particles that are driven out of the boiler by the flue gases through the chimney. ASTM C 618 classifies fly ash based on chemical requirements and physical requirements into Class F and Class $\mathrm{C}$ [13]. The requirements for class $\mathrm{F}$ is shown in Table 1.

Table 1. Chemical requirements [13]

\begin{tabular}{|l|l|}
\hline & Class $\mathrm{F}$ \\
\hline $\mathrm{SiO}_{2}+\mathrm{Al}_{2} \mathrm{O}_{3}+\mathrm{Fe}_{2} \mathrm{O}_{3}, \min , \%$ & 70.0 \\
\hline$(\mathrm{SO} 3), \max , \%$ & 5.0 \\
\hline Moisture content, max, \% & 3.0 \\
\hline Loss on ignition, max, \% & 6.0 \\
\hline
\end{tabular}

The fly ash used in the current study is manufactured at Iskenderun power station in compliance with DIN EN 450 - fly ash for concrete and is classified as class F in accordance to ASTM C 618. The product specifications as reported by the manufacturer is shown in Table 2 .

Table 2. Fly ash properties

\begin{tabular}{|l|l|}
\hline Parameter & Average \\
\hline Loss On Ignition, $\%$ & 2.6 \\
\hline Fineness $>0.045 \mathrm{~mm}, \%$ & 15.1 \\
\hline Chloride $(\mathrm{CI}), \%$ & 0.012 \\
\hline Gross Density, $\mathrm{kg} / \mathrm{m}^{3}$ & 2330 \\
\hline
\end{tabular}

The specific surface area of the fly ash is 0.356 $\mathrm{gm} / \mathrm{m}^{2}$, the maximum grain size is $350 \mu \mathrm{m}$, the mass percentage retained on $45 \mu \mathrm{m}$ (no. 325) sieve is $64.25 \%$ which exceeds ASTM C 618 limit of $34 \%$ for fly ash designated to be used as a Pozzolan material in normal concrete. The percentage of fine materials was disregarded due to the fact that the fly ash is being used as a cementitious material and thus, finer particles results in more chemically active material. The particle size distribution is shown in Fig. 1.

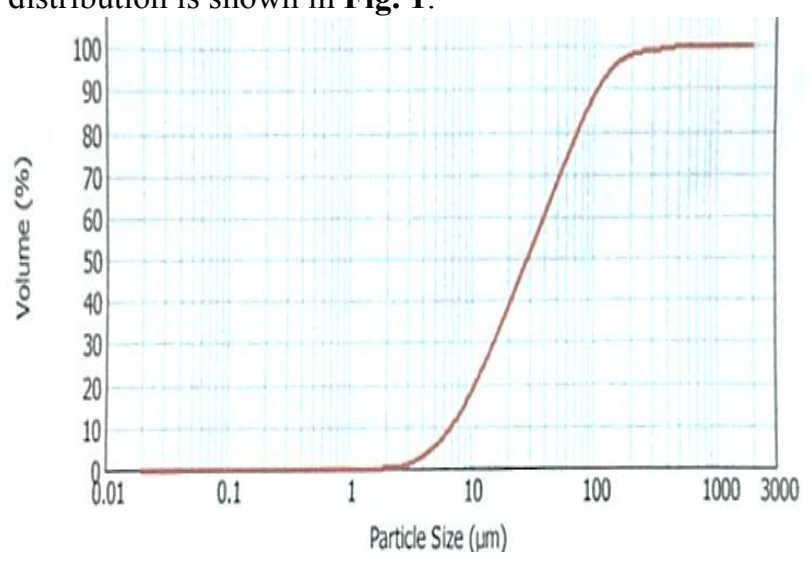

Fig. 1. Fly ash particle size distribution

The chemical composition analysis was conducted in the General Laboratories Department of the Iraq Geological Survey in Baghdad. The detailed results are tabulated in Table 3.

Table 3. Fly ash chemical composition

\begin{tabular}{|l|l|l|l|l|l|l|l|}
\hline Oxide & $\mathrm{SiO}_{2}$ & $\mathrm{Al}_{2} \mathrm{O}_{3}$ & $\mathrm{CaO}$ & $\mathrm{SO}_{3}$ & $\mathrm{LOI}$ & $\mathrm{Na}_{2} \mathrm{O}$ & $\mathrm{K}_{2} \mathrm{O}$ \\
\hline Content & 58.13 & 18.89 & 1.60 & 0.18 & 3.28 & 1.27 & 1.46 \\
\hline
\end{tabular}

\subsubsection{Sodium Hydroxide}

Commercially available sodium hydroxide $(\mathrm{NaOH})$, known as caustic soda, was used for the current study. The physical appearance is white solid smooth shiny flakes. The purity of the sodium hydroxide was measured in the General Laboratories Department of the Iraq Geological Survey in Baghdad and was reported as $98.8 \%$. The product is hydroscopic thus; it was kept in sealed airtight bags in order to protect the flakes from absorbing moisture from the air. Sodium hydroxide reacts with carbon dioxide $\left(\mathrm{CO}_{2}\right)$ from the air to form sodium bicarbonate $(\mathrm{NaHCO})$ and this is another reason for protecting sodium hydroxide from the exposure to air.

\subsubsection{Sodium silicate}

Sodium Silicate $\left(\mathrm{Na}_{2} \mathrm{SiO}_{3}\right)$ has been supplied from the local market. The consistency is a liquid of 0.55 water content by mass.

\subsubsection{Coarse aggregate}

The coarse aggregate that was used for the current study was normal weight crushed aggregate with maximum size of $12.5 \mathrm{~mm}$ and conforming to ASTM C 33 [14] as shown in Fig. 2. The bulk density of the coarse aggregate was found to be $2665 \mathrm{~kg} / \mathrm{m}^{3}$, the absorption is $0.5 \%$ and the sulfate content is $0.08 \%$. 


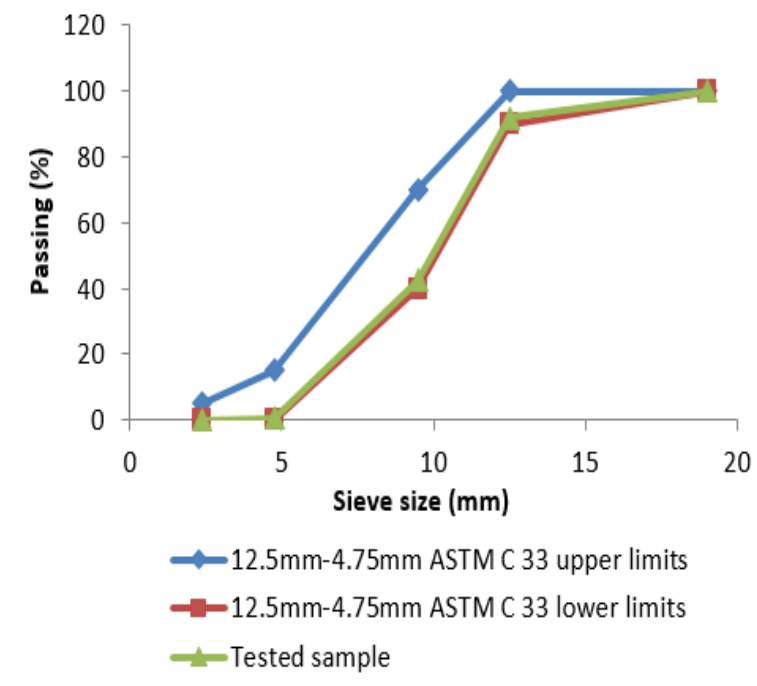

Fig. 2. Course aggregate sieve analysis

\subsubsection{Fine aggregate}

Clean and washed river sand was used in the current study. ASTM C 33-03 specifications [14] were used for the standardization of the sand; it was found that the tested sand conformed to the specifications as shown in Fig. 3. The bulk density of the fine aggregate was found to be $2600 \mathrm{~kg} / \mathrm{m}^{3}$ and the sulfate content is $0.13 \%$.

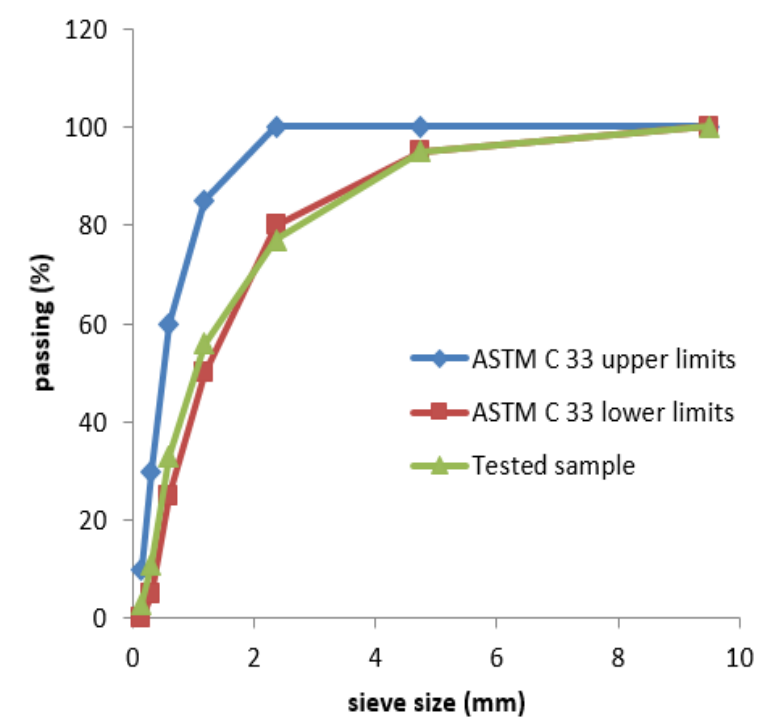

Fig. 3. Fine aggregate sieve analysis

\subsubsection{Superplasticizer}

The superplasticizer used is the KUT PLAST SP 400 high range water reducing admixture of relative density 1.22-1.24 which is a solution based on modified sulfonated naphthalene formaldehyde condensate. The product was purchased from the local market and was stored in a place protected from extreme temperature.

\subsubsection{Water}

Clean tap water was used for the sodium hydroxide solution preparation and as an extra mixing water for more workable Geopolymer concrete.

\subsection{Mixing procedure}

The first step of mixing was to prepare the alkaline solution by mixing the water with the sodium hydroxide flakes with stirring by a rod for 30 seconds. The solution then was left for at least 1 hour for the complete dissolving of the $\mathrm{NaOH}$ flakes. Then the sodium silicate liquid was added to the $\mathrm{NaOH}$ solution with stirring for 1 minute and left for at least 30 minutes in the laboratory. The fine and coarse aggregate were mixed together in the electric pan mixer for 2 minutes then the fly ash was added and mixed for 1 minute. The HRWA superplasticizer was added to the alkaline solution not later than 2 minutes of the addition of the alkaline solution to the dry materials. The HRWA superplasticizer was mixed for 20 seconds with the alkaline solution, then directly added to the dry materials in the mixer. The mixing lasted for 4-7 minutes in the mixer. When extra-water was required, it was added to the wet mix at least 1 minute after the mixing of the alkaline solution with the dry materials.

\subsection{Curing procedure}

The curing of the Geopolymer concrete differs from that of the Portland cement concrete. The former is cured by heat, while the latter is cured by water. The specimens were cured by two methods: One of the methods is the oven discontinuous curing, which expose the Geopolymer concrete specimens to temperature in the oven for few hours then stopping the oven to let it cool down to the ambient temperature. This method was applied to mix 3 through mix 6 . The curing regime is illustrated in Fig. 4, 5, and 6. The oven temperature is $90^{\circ} \mathrm{C}$ for mix 3,4 , and 5 and is $80^{\circ} \mathrm{C}$ for mix 6 . The second curing method is exposing of the specimens to ambient temperature only.

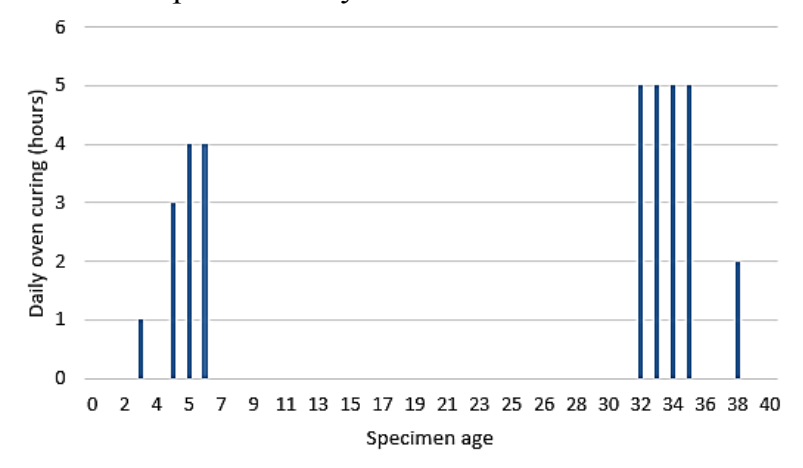

Fig. 4. Discontinuous oven curing of mix 3 


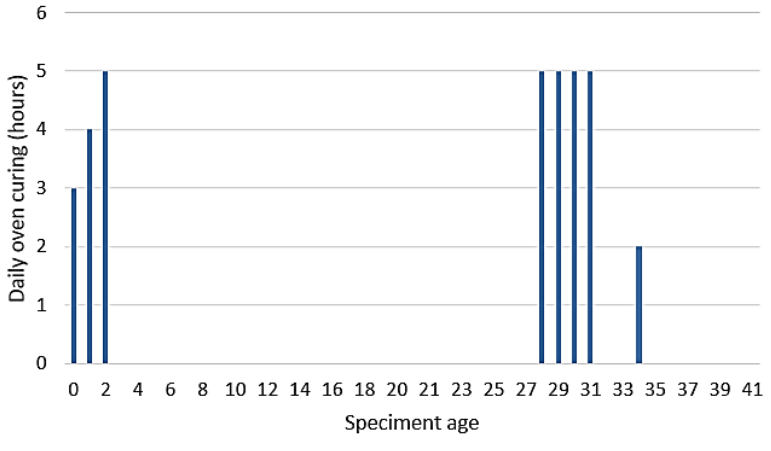

Fig. 5. Discontinuous oven curing of mix 4

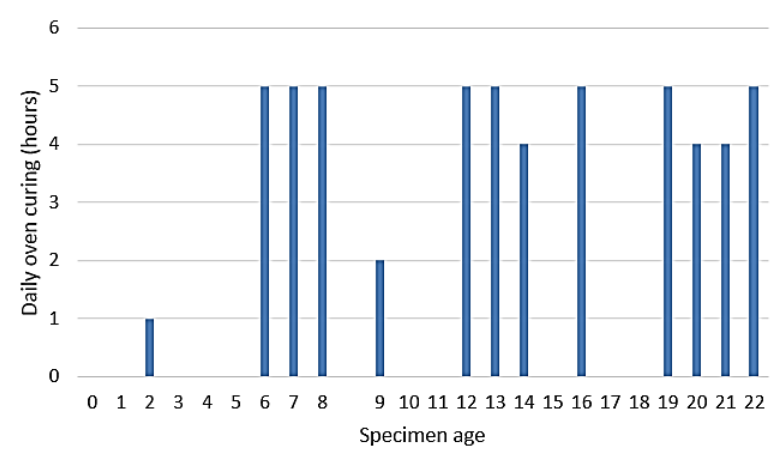

Fig. 6. Discontinuous oven curing of mix 5

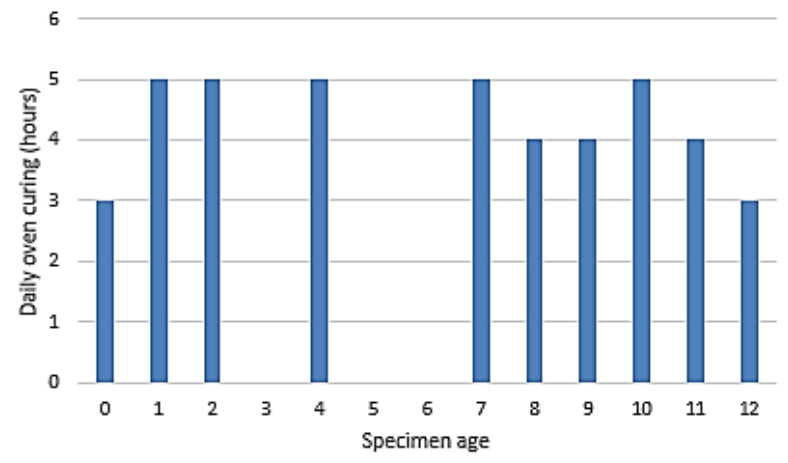

Fig. 7. Discontinuous oven curing of mix 6

\section{Experimental study}

\section{1 mixture characteristics}

The selection of the parameters that was based on their influence on the fresh and hardened properties of the Geopolymer concrete. Geopolymerization of the precursors of the mineral-polymer is series of chemical processes that include reactions, forming, and arranging to result in the Geopolymer structure. It has been found by many researchers that both the alkaline solution properties and the oxides in the fly ash have vast impact on the properties of the mineralpolymers [15-20]

In the current study $\mathrm{NaOH}$ molarity was kept constant at $12 \mathrm{M}$. The effect of the molarity of $\mathrm{NaOH}$ is controversial. Some studies indicated that the higher the
$\mathrm{NaOH}$ concentration, the higher the compressive strength [21]. Some studies show that high $\mathrm{NaOH}$ concentration results in lower compressive strength [17]. The molarity of the caustic soda solution affects the setting time of the Geopolymer concrete [16].

The percent of $\mathrm{Na}_{2} \mathrm{O}$ in the solution can be controlled by the concentration of $\mathrm{NaOH}$ and the ratio of sodium silicates to sodium hydroxide (SS/SH), see Fig. 8. The fly ash used in the current study has $1.27 \%$ by weight of $\mathrm{Na}_{2} \mathrm{O}$. Depending on the molarity and $\mathrm{SS} / \mathrm{SH}$ ratio of the mixtures shown in Table $4, \mathrm{Na}_{2} \mathrm{O}$ from fly ash can contribute in a range of $(5-15) \%$ of the total $\mathrm{Na}_{2} \mathrm{O}$ weight of the Geopolymer.

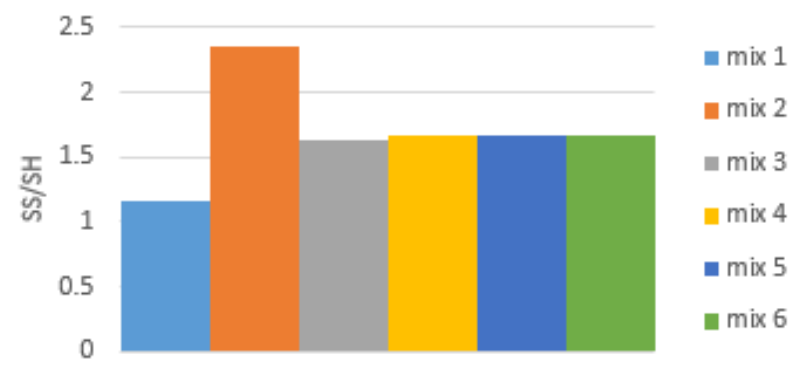

Fig. 8. The ratio of sodium silicate to sodium hydroxide in the mixes

The weight of the fly ash in the mix is an important factor for the compressive strength of the Geopolymer concrete. The ratio of Fly ash $/\left(\mathrm{Na}_{2} \mathrm{O}+\mathrm{SiO}_{2}\right)$ and Fly ash/(Fly ash $\left.+\mathrm{Na}_{2} \mathrm{O}+\mathrm{SiO}_{2}\right)$ is considered to be utilized for studying the contribution of fly ash quantity relative to $\mathrm{Na}_{2} \mathrm{O}$, and $\mathrm{SiO}_{2}$ in the various mixes.

Table 4. Parameters of the Geopolymer of current study

\begin{tabular}{|c|c|c|c|c|c|c|c|c|c|}
\hline $\begin{array}{l}3 \\
\not{x} \\
Z \\
0\end{array}$ & 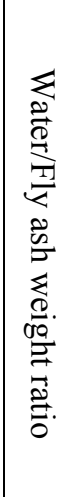 & 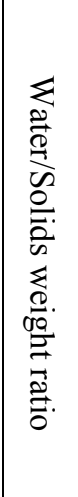 & 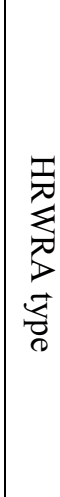 & 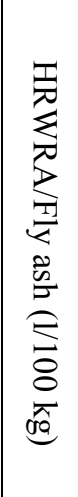 & \begin{tabular}{l}
3 \\
0 \\
0 \\
\multirow{2}{*}{}
\end{tabular} & 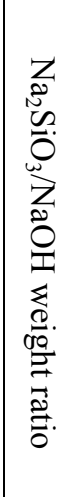 & 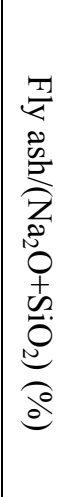 & 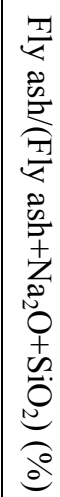 & 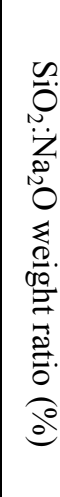 \\
\hline 1 & 0.35 & 0.30 & $\mathrm{~K}^{*}$ & 2.28 & 12 & 1.17 & 614 & 86 & 77 \\
\hline 2 & 0.32 & 0.27 & $\mathrm{~K}^{*}$ & 2.57 & 12 & 2.35 & 665 & 87 & 113 \\
\hline 3 & 0.32 & 0.26 & $\mathrm{~K}^{*}$ & 2.94 & 12 & 1.64 & 504 & 83 & 94 \\
\hline 4 & 0.32 & 0.26 & $\mathrm{~K}^{*}$ & 3.33 & 12 & 1.66 & 498 & 83 & 94 \\
\hline 5 & 0.32 & 0.26 & $\mathrm{~K}^{*}$ & 3.33 & 12 & 1.66 & 498 & 83 & 94 \\
\hline 6 & 0.32 & 0.26 & $\mathrm{~K}^{*}$ & 4.12 & 12 & 1.66 & 498 & 83 & 94 \\
\hline
\end{tabular}




\subsection{Mixture proportions}

The mix proportions for the six mixtures of the current study is shown in Table 5. The quantities are for one cubic meter of Geopolymer concrete.

Table 5. Mixture proportions

\begin{tabular}{|c|c|c|c|c|c|c|c|}
\hline 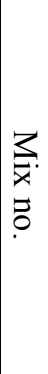 & 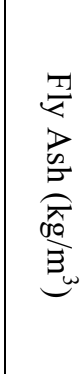 & 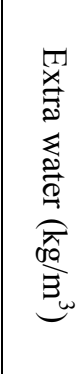 & 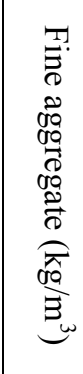 & 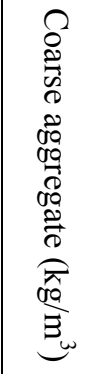 & 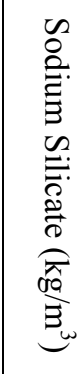 & 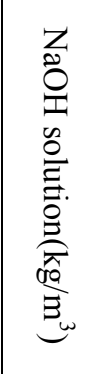 & 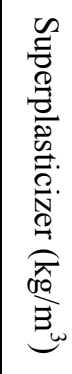 \\
\hline 1 & 452 & 46 & 751 & 858 & 104 & 89 & 13 \\
\hline 2 & 410 & 43 & 768 & 987 & 107 & 45 & 13 \\
\hline 3 & 414 & 11 & 723 & 1000 & 130 & 79 & 15 \\
\hline 4 & 413 & 9 & 721 & 998 & 131 & 79 & 17 \\
\hline 5 & 413 & 9 & 721 & 998 & 131 & 79 & 17 \\
\hline 6 & 412 & 9 & 719 & 995 & 131 & 79 & 21 \\
\hline
\end{tabular}

The curing type, curing temperature and ambient temperature are detailed in Table 7

\subsection{Testing Methods}

\subsubsection{Workability}

Slump test as an indicator for the concrete workability was conducted in compliance with ASTM C 43 specifications [22]

\subsubsection{Compressive strength}

Cylinders with $\mathrm{d}=100 \mathrm{~cm}$ and $\mathrm{h}=200 \mathrm{~cm}$ were used to shape the Geopolymer concrete specimens. The specimens were tested using $2000 \mathrm{kN}$ compression testing machine. The test specimens and procedures were conducted in compliance with ASTM C 39-05 specifications [23].

\section{Results and discussion}

\subsection{Compressive strength}

The compressive strengths of the tested cylinders are shown in Table 7. It can be seen that the compressive strength of mix 1 which was cured in ambient temperature of $43^{\circ} \mathrm{C}$ has a progressive strength with time and reached $29.21 \mathrm{MPa}$ at 40 days. While for mix 2 which was also cured at ambient temperature of $43^{\circ} \mathrm{C}$ the compressive strength is $23.45 \mathrm{MPa}$ at 40 days. Referring to Table 5, this increase in strength can be explained by higher percentage of the fly ash that leads to higher binder in the matrix. Another factor that led to the higher strength for mix 1 is the $\mathrm{Na}_{2} \mathrm{SiO}_{3} / \mathrm{NaOH}$ weight ratio which when increased from 1.17 to 2.35 negatively affected the compressive strength. Table 4 shows that water to fly ash ratio for mix 2 is 0.32 which is lower than that for mix $1(0.35)$. This decrease in water was not enough to compensate the negative effect of the high $\mathrm{SS} / \mathrm{SH}$ ratio. This leads to a conclusion that $\mathrm{SS} / \mathrm{SH}$ ratio is a vital factor when designing Geopolymer concrete.

Mixes 3 through 6 were cured discontinuously in the oven. For mix 3, the specimens were left atambient temperature of $42^{\circ} \mathrm{C}$ for the first three days after casting. Then they were exposed to oven curing for 1 hour at $90{ }^{\circ} \mathrm{C}$ then left at ambient temperature of $42^{\circ} \mathrm{C}$ until they were tested for the compressive strength at the fourth day (see Fig. 4). The development of strength was noticeable if compared to mix 1 and mix 2 . One hour of discontinuous curing was enough to result in a compressive strength after only four days that is close to the compressive strength of mix 1 after 7 days and to mix 2 at 40 days. Discontinuous curing for $\operatorname{mix} 3$ resulted in $40.58 \mathrm{MPa}$ at 40 days age.

Discontinuous curing of 12 hours within 3 days for mix 4 (see Fig. 5) resulted in a compressive strength which is almost equal to that of mix 3 at 21 days. In spite of this improvement in the early strength of mix 4, the strength improvement at later ages is more obvious for $\operatorname{mix} 3$ than mix 4 . Both mix 3 and mix 4 were cured discontinuously for 40 days with total oven curing of 34 hours, but the compressive strength of mix 3 was 40.58 MPa which is $23 \%$ more than that of mix 4 at age 40 days. Everything is the same for mix 3 and mix 4 except the curing regime. To explain the reason behind the divergence in the compressive strength of the two mixes, it is important to mention that mix 3 was left in the ambient temperature for 3 days as a rest period prior to any oven curing. Mix 4 was directly cured in the oven after the casting in the molds. Curing regime has enhanced the geopolymerization of the goepolymer concrete through the activation of the chemical reactions of the fly ash with the alkaline solution in the early age of mix 4 , but mix 3 has developed 40 days compressive strength of $23 \%$ higher than mix 4 .

Mix 5 is identical to mix 4 and was left in the ambient temperature for two days of rest period then cured at $90^{\circ} \mathrm{C}$ for one hour then left in the ambient temperature for three days and discontinuous oven curing was then resumed. The compressive strength at 21 days of mix 5 is almost equal to that of mix 4 in spite of the fact that mix 5 oven curing time is remarkably more than that of mix 4 . The effect of the rest period can be observed from the need of mix 5 for more oven curing to reach the compressive strength of mix 4 at the same age.

The influence of the rest period was also inspected in mix 6. No rest period was allowed for mix 6 (which is identical to mix 4 and mix 5). It is obvious that the progress of the compressive strength for mix 6 is higher than that for mix 5 in spite of the drop in the ambient temperature to $36^{\circ} \mathrm{C}$ which was $38^{\circ} \mathrm{C}$ in the case of mix 5. Again, this divergence in compressive strength is demonstrated by the influence of the rest period. 
Table 6 compares the compressive strength of mix 3 , $\operatorname{mix} 4$, mix 5, and mix 6 for specific curing times and shows that for mixes without rest period, a higher early compressive strength can be obtained by the same oven curing time and in earlier age than the mixes with the rest periods.

Table 6. Early strength comparison of mixes 3 through 6

\begin{tabular}{|l|l|l|l|l|}
\hline Mix no. & $\begin{array}{l}\text { Rest } \\
\text { period }\end{array}$ & $\begin{array}{l}\text { Age } \\
\text { (days) }\end{array}$ & $\begin{array}{l}\text { Oven } \\
\text { curing } \\
\text { (hours) }\end{array}$ & $\begin{array}{l}\text { Compressive } \\
\text { strength } \\
\text { (MPa) }\end{array}$ \\
\hline 3 & Yes & 7 & 12 & 23.60 \\
\hline 4 & No & 3 & 12 & 27.00 \\
\hline 5 & Yes & 8 & 16 & 24.15 \\
\hline 6 & No & 7 & 18 & 31.74 \\
\hline
\end{tabular}

\section{Conclusions}

One of the main expenses associated with the production of the Geopolymer concrete is the oven curing costs. The following conclusions summarize the effect of the investigated factors on both compressive strength and the cost of the Geopolymer concrete:

1. The ratio of $\mathrm{SS} / \mathrm{SH}$ is an important factor that influences the compressive strength of the Geopolymer concrete and thus, trail mixes of various $\mathrm{SS} / \mathrm{SH}$ for optimization are needed to result in the required compressive strength with the least oven curing. A value of 1.17 was found the best for ambient cured Geopolymer concrete.

2. Discontinuous oven curing, even for short period of 1 hour significantly improves the compressive strength. An increase of $56 \%$ in the compressive strength was achieved by one hour of oven curing.

3. In the case of discontinuous curing, the rest period when allowed to the Geopolymer concrete upon casting results in higher 40 days compressive strength than that of Geopolymer concrete which is directly oven cured. The strength improvement is remarkably evident within the period from 28 days to 40 days.

4. The early strength improvement of Geopolymer without rest period excitation is higher than when rest period is allowed. In one example, it has shown a compressive strength of $23 \%$ higher at 3 days age than the Geopolymer concrete without rest period excitation.

5. The ambient temperature plays a major role in the Geopolymerization process of the Geopolymer concrete in discontinuous curing. Within the experimental tests temperature range of $(43-36)^{\circ} \mathrm{C}$, the higher the ambient temperature the higher the compressive strength.
Table 7. Compressive strength of the tested cylinders

\begin{tabular}{|c|c|c|c|c|c|c|}
\hline $\begin{array}{l}3 \\
3 \\
\vdots \\
0\end{array}$ & 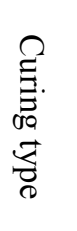 & 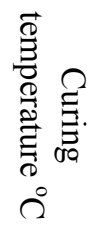 & 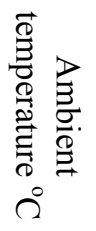 & 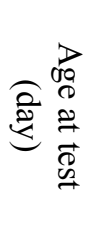 & 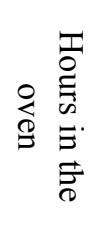 & 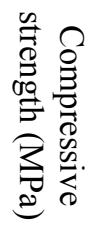 \\
\hline \multirow[t]{3}{*}{1} & \multirow[t]{3}{*}{$\mathrm{A}^{*}$} & \multirow[t]{3}{*}{43} & \multirow[t]{3}{*}{43} & 7 & 0 & 22.90 \\
\hline & & & & 14 & 0 & 24.62 \\
\hline & & & & 40 & 0 & 29.21 \\
\hline \multirow[t]{3}{*}{2} & \multirow[t]{3}{*}{$\mathrm{A}^{*}$} & \multirow[t]{3}{*}{43} & \multirow[t]{3}{*}{43} & 7 & 0 & 15.13 \\
\hline & & & & 14 & 0 & 16.00 \\
\hline & & & & 40 & 0 & 23.45 \\
\hline \multirow[t]{6}{*}{3} & \multirow[t]{6}{*}{$\mathrm{O}^{* *}$} & \multirow[t]{6}{*}{90} & \multirow[t]{6}{*}{42} & 4 & 1 & 22.00 \\
\hline & & & & 7 & 12 & 23.60 \\
\hline & & & & 18 & 12 & 25.10 \\
\hline & & & & 21 & 12 & 27.10 \\
\hline & & & & 25 & 12 & 35.77 \\
\hline & & & & 40 & 34 & 40.58 \\
\hline \multirow[t]{4}{*}{4} & \multirow[t]{4}{*}{$\mathrm{O} * *$} & \multirow[t]{4}{*}{90} & \multirow[t]{4}{*}{41} & 3 & 12 & 27.00 \\
\hline & & & & 13 & 12 & 30.00 \\
\hline & & & & 21 & 12 & 30.78 \\
\hline & & & & 40 & 34 & 32.97 \\
\hline \multirow[t]{3}{*}{5} & \multirow[t]{3}{*}{$\mathrm{O} * *$} & \multirow[t]{3}{*}{90} & \multirow[t]{3}{*}{38} & 8 & 16 & 24.15 \\
\hline & & & & 14 & 18 & 29.27 \\
\hline & & & & 21 & 55 & 30.35 \\
\hline \multirow[t]{3}{*}{6} & \multirow[t]{3}{*}{$\mathrm{O} * *$} & \multirow[t]{3}{*}{80} & \multirow[t]{3}{*}{36} & 7 & 18 & 31.74 \\
\hline & & & & 11 & 40 & 32.09 \\
\hline & & & & 12 & 43 & 33.83 \\
\hline
\end{tabular}

$\mathrm{A}^{*}$ Cured in ambient temperature

$\mathrm{O} * *$ Cured in an electrical oven

\section{References}

[1] M. Albitar, M. M. Ali, P. Visintin and M. Drechsler, Construction and Building Materials, 136, (2017)

[2] C. Horsley, M. H. Emmert and A. Sakulich, 184,(2016)

[3] S. Ruan and C. Unluer, Journal of Cleaner Production, 137,(2016)

[4] A. Palomoa, M. Grutzeckb and M. Blancoa, Cement and Concrete Research, 29, (1999)

[5] U.S. Geological Survey, Reston, Virginia, (2015)

[6] S. Saha and C. Rajasekaran, Construction and Building Materials, 146, (2017)

[7] S. Demie and M. F. Nuruddin, Construction and Building Materials, 41, (2013)

[8] R. Derabla and M. L. Benmalek, Construction and Building Materials, 66, (2014)

[9] M. R. Hall and K. B. Najim, Construction and Building Materials, 73, (2014)

[10] K. Ma, J. Feng, G. Long, Y. Xie and X. Chen, Construction and Building Materials, 143,(2017) 
[11] Okamura, Hajime and M. Ouchi, Journal of Advanced Concrete Technology, 1, 1, (2003)

[12] R. Rani and M. K. Jain, Powder Technology, (2017)

[13] ASTM C618, ASTM International, (2015)

[14] ASTM C33, ASTM International, (2015)

[15] C. B. Cheah, M. H. Samsudin and M. Ramli, Journal of Cleaner Production, (2016)

[16] Y.-K. Cho, S.-W. Yoo, S.-H. Jung, K.-M. Lee and S.-J. Kwon, Construction and Building Materials, 145, (2017)

[17] M. N. Hadi, N. A. Farhan and M. N. Sheikh, Construction and Building Materials, 145, (2017)

[18] A. Nazari, H. Khanmohammadi, M. Amini, H. Hajiallahyari and A. Rahimi, Materials and Design, 41, (2012)

[19] A. Sharmin, U. J. Alengaram, M. Z. Jumaat, M. O. Yusuf, S. A. Kabir and I. I. Bashar, Construction and Building Materials, 144, (2017)

[20] A. A. Siyala, K. A. Azizlia, Z. Mana and H. Ullaha, Procedia Engineering, 148, (2016)

[21] K.-W. Lo, K.-L. Lin, T.-W. Cheng, Y.-M. Chang and J.-Y. Lan, Construction and Building Materials, 143, (2017)

[22] ASTM C143, ASTM International, (2015)

[23] ASTM C39, ASTM International, (2015) 